\title{
Nitrate pollution in the Delicias-Meoqui aquifer of Chihuahua, Mexico
}

\author{
M. S. Espino ${ }^{1}$, H. O. Rubio ${ }^{2}$ \& C. J. Navarro ${ }^{1}$ \\ ${ }^{1}$ Faculty of Engineering, Autonomous University of Chihuahua, Mexico \\ ${ }^{2}$ Faculty of Zootechnic, Autonomous University of Chihuahua, Mexico
}

\begin{abstract}
Nitrate concentration higher than $10 \mathrm{mg} \mathrm{L}^{-1}$ in drinking water can cause health problems, especially in infants. Nitrates from a variety of surface and subsurface sources, such as fertilizers, are soluble in water and can leach into groundwater causing quality degradation. Groundwater from Delicias-Meoqui aquifer supplies drinking and irrigation water to six municipalities in the state of Chihuahua. A part of the area overlying this aquifer corresponds to the irrigation district DR-005, one of the most important hydro-agricultural works in Mexico. An evaluation was conducted using historical water quality data from 134 drinking water wells to make a preliminary diagnosis concerning nitrate presence in that aquifer. Water analyses showed that $34 \%$ of samples have nitrate concentrations equal or higher than the $10 \mathrm{mg} \mathrm{L}^{-1}$ drinking water standard. Most of these samples were from the Delicias, Saucillo and Meoqui municipalities, with approximately 180,000 inhabitants total. Undoubtedly, the high nitrate concentrations can be attributed to pollution within the irrigation district DR-005 where nitrogen fertilizers in large quantities are applied, dissolve in water and move with it through the soil profile down to groundwater. This preliminary evaluation will contribute to the development of preventative strategies that can protect groundwater in proximity to agricultural production systems from nitrate contamination.
\end{abstract}

Keywords: nitrate, fertilizers, leaching, groundwater pollution, Delicias-Meoqui aquifer, Chihuahua, México. 


\section{Introduction}

Nitrate is constituted by the $\mathrm{NO}_{3}{ }^{-}$anion and its presence in the environment results from the decomposition of nitrogen compounds. High concentrations of nitrates in drinking water can cause human health problems [1]. When nitrate undergo reduction to nitrite $\left(\mathrm{NO}_{2}{ }^{-}\right)$, a process which occurs in the digestive tract by faecal microorganisms, blood oxygen transport is disabled causing the disease named metahemoglobinemia [2, 3]; also known, as baby blue syndrome concerning infants [4]. Other researches have associated nitrate with certain type of lymphoma [2] and have suggested the risk of acquiring cancer in areas where water with high levels of nitrate is consumed [5]. Pertaining to animal special cases, it has been demonstrated than consumption of these nitrogen compounds can cause birth defects $[6,7]$.

The presence of nitrate in water is seasonal and variable [8]. Because of their negative charge these ions may have great mobility [9] and can pollute surface water and groundwater. Rubio et al., [10] found nitrate levels up to $10.53 \mathrm{mg} \mathrm{L}^{-1}$ in water samples of the Río Florido, which is a Río Conchos tributary. These values are higher than the International and Mexican standards of $10 \mathrm{mg} \mathrm{N}-\mathrm{NO}_{3}^{-} \mathrm{L}^{-1}$ in drinking water that were established to prevent human health problems $[11,12]$.

Aquifers can become polluted from nitrogen leaching from urban or rural wastewater, as is the case of fertilizers that are commonly applied in agricultural irrigation. A study in the United Sates of America showed that $11 \%$ of sampled wells had nitrate concentrations higher than $10 \mathrm{mg} \mathrm{L}^{-1}[13]$. In the special case of the state of Chihuahua, groundwater is the main hydrological resource both for drinking water supply and for industrial and agricultural irrigation. The DeliciasMeoqui Aquifer (DMA) is located in the central-east portion of the hydrologic region RH-24 of Río Conchos-Bravo watershed [14]. Leaching of nitrogen residues are favored by several factors including the high permeability of aquifer, the low slope on the Delicias-Meoqui valley and the periodical application of large quantities of fertilizers in the DR-005. Presently, it is possible to find some data about nitrate concentration in drinking water wells for those localities within the DMA area. Nevertheless, a comprehensive evaluation of the influence of irrigation activities on groundwater quality does not exist.

The objective of this study was to perform a preliminary diagnosis of the presence of nitrate in the Delicias-Meoqui aquifer based on existing historical data of groundwater quality. The results will establish the basis for planning a more detailed study which includes a formal monitoring program and the geochemical evaluation of water quality parameters. These will contribute to the determination of strategies that would diminish the risk of aquifer contamination.

\section{Materials and methods}

The climate in the study area is arid, with extreme temperatures and with an average precipitation of $319 \mathrm{~mm} \mathrm{year}^{-1}$ [15]. The aquifer is constituted by alluvial material of medium to high permeability. Its recharge occurs by pluvial 
precipitation over the area and surrounding hills, irrigation returns, and percolation water from the Conchos and San Pedro rivers. Groundwater flow agrees with these rivers' path, south to north [14]. About 1,000 wells pierce the DMA; most of them, are used for agricultural irrigation. However, part of the extracted volume is used to satisfy the drinking water requirements of the population living in Delicias, Meoqui, Julimes, Rosales, Saucillo and La Cruz municipalities.

A part of the area occupied by this aquifer corresponds to the irrigation district (DR-005) which is one of the most important hydro-agricultural works in the country. Crop production including wheat, corn, alfalfa, sorghum, soybeans, chilli, onion, walnut and vegetables occupies approximately 90,000 ha of irrigated land. Typical agricultural activities include the use of nitrogen and phosphate compounds as fertilizers, such as anhydrous ammonia, urea and ammonium phosphate. The doses vary between 100 and $270 \mathrm{~kg} \mathrm{ha}^{-1}$ [16].

Historical data concerning aquifer characteristics and groundwater quality were reviewed and analyzed a total of 134 wells. The source for this information was federal and state governmental agencies. Water groups were established by means of hydrochemical tools using data available for 2003, 2004, and 2005. Also, qualitative aspects related with relevant substances for human health were evaluated in drinking water sources of the area.

In the area is notorious calcium and sodium sulfate as well as calcium and sodium bicarbonate, on agree with geological characteristics of arid zones. Important elements like arsenic, fluoride and nitrate are present in several groundwater sources in concentrations that exceeded the drinking water quality guidelines. Some of these wells had high levels of dissolved solids and sulfate too. Arsenic and fluoride exist on groundwater of several states of Mexico, as in many regions of the world. It's a consequence of nature of rocks which are in contact with water. The arsenic and/or fluoride high levels in drinking water problem of 43 communities in the region of study has been attended by Chihuahua state authorities by means the establishment of local treatment systems. They are based on reverse osmosis principle to demineralize the water fraction which is ingested by consumers.

\section{Results and discussion}

The quality data review on 134 drinking water samples demonstrated that $34 \%$ of the wells had concentrations equal or exceeding $10 \mathrm{mg} \mathrm{N}-\mathrm{NO}_{3}{ }^{-} \mathrm{L}^{-1}$ (Table 1). Communities of Delicias, Saucillo and Meoqui are particularly important because they have $50 \%, 40 \%$ and $29 \%$ of wells above or at the permissible limit for nitrate, respectively. These communities have a total population of more than 180,000 inhabitants. Of the 46 localities with nitrate above or in the limit, only 15 have a demineralization treatment system [17]. These results are of practical importance considering that high levels of nitrate in drinking water have been associated with urothelial diseases, including cancer [18] and a type of lymphoma [19]. 
Examination of data showed four distinct zones of high levels of nitrate. These areas are shown in Figure 1, and are described below. Zone 1: The northwest portion of aquifer, with some localities within the Meoqui municipality (Diez de Mayo, Sta. Rita de Casia, Barranco Blanco, Potrero del Llano, Felipe Angeles). Zone 2: An area between Meoqui (Loreto, Francisco Portillo, Nuevo Loreto) and Delicias (Cuauhtémoc, La Gomeña, Morelos, Ampliación Mercedes). Zone 3: Some localities near Delicias (Colonia Campesina, Ciudad Delicias, Vicente Guerrero, Santa Fe) and Saucillo (Sta. Rosa, Las Varas, Orranteño). Zone 4: Several localities south of Saucillo (Armendáriz, San Francisco de Mezquital, Vicente Guerrero, Ciudad Saucillo, Puerto del Toro).

These four identified areas represent non-point or dispersed pollution zones within the irrigation district DR-005 influence area. According to official reports [14], this is the principal recharge area for the aquifer; therefore, the zone where water is added to the groundwater system (Figure 2). The total recharge includes rain infiltration, the water irrigation returns of surface water and the leakages from domestic pipelines. Its value reaches $217.39 \mathrm{Hm}^{3} /$ year. It can be noticed in Figure 2 that the higher values of recharge zone (where $81 \%$ of total aquifer recharge occurs) are found in zones Z-5, Z-6 and Z-9, which corresponds geographically to the surface occupied by the irrigation district DR-005.

Table 1: $\quad$ Summary of drinking water wells with high nitrate concentration.

\begin{tabular}{|c|c|c|c|}
\hline \multirow[b]{2}{*}{ MUNICIPALITY } & \multicolumn{2}{|c|}{ Number of wells } & \multirow{2}{*}{$\begin{array}{c}\text { Percentage of } \\
\text { wells with high } \\
\text { nitrate } \\
\text { concentration } \\
(\%)\end{array}$} \\
\hline & Total & $\begin{array}{l}\text { With high nitrate } \\
\text { concentration }(*)\end{array}$ & \\
\hline Julimes & 9 & 1 & 11.1 \\
\hline Rosales & 16 & 4 & 25.0 \\
\hline La Cruz & 8 & 0 & 0.0 \\
\hline Meoqui & 31 & 9 & 29.0 \\
\hline Saucillo & 30 & 12 & 40.0 \\
\hline Delicias & 40 & 20 & 50.0 \\
\hline TOTAL & 134 & 46 & 34.3 \\
\hline
\end{tabular}

${ }^{(*)}$ Nitrate concentration $\geq 10 \mathrm{mg} \mathrm{N}-\mathrm{NO}_{3}{ }^{-} / \mathrm{L}$.

In comparison with Figure 1, we notice that this region also corresponds with the nitrate leaching zone. Hence, it is possible to establish a close relationship between groundwater quality and nitrate pollution from irrigation activities. Interestingly, a study by Nolan [20] concluded that six variables will predict the presence of more than $4 \mathrm{mg} \mathrm{L}^{-1}$ of nitrate in the ground water: nitrogen fertilizer, percent cropland-pasture, population density, percent well-drained soils, depth of the seasonally high water table and the presence or absence of a bedrock fracture zone within an aquifer. These variables are maximized in the Delicias-Meoqui 
aquifer, where the nitrate in groundwater represents a potential hazard to human health as well as for the whole ecosystem.

A prominent result is that $50 \%$ of drinking water wells within the Delicias municipality $(115,000$ inhabitants) tested is above the nitrate permissible limits. This area corresponds to the most exploited part of the aquifer, with local flow lines moving in radial direction to higher nitrate concentration sites [14]. The high incidence of nitrate in the Delicias area can be associated with nitrogen compounds leached from irrigation as well as from livestock facilities which are common in the area. Another important nitrate source in the rural areas may be septic systems and in urban zones the leakage from sanitary sewers and effluents from treated and raw sewage discharged at surface water bodies.

Necessary actions to reduce potential risks of pollution in the DMA include the application of fertilizers at tested agronomic doses to avoid nitrogen leakage into the groundwater saturated zone. Also, a careful management during storage and cleaning of fertilizer containers is needed, as well as removal of organic wastes from livestock, adequate maintenance of sanitary sewers, and an advanced wastewater treatment that removes nitrogen residues capable of polluting groundwater.

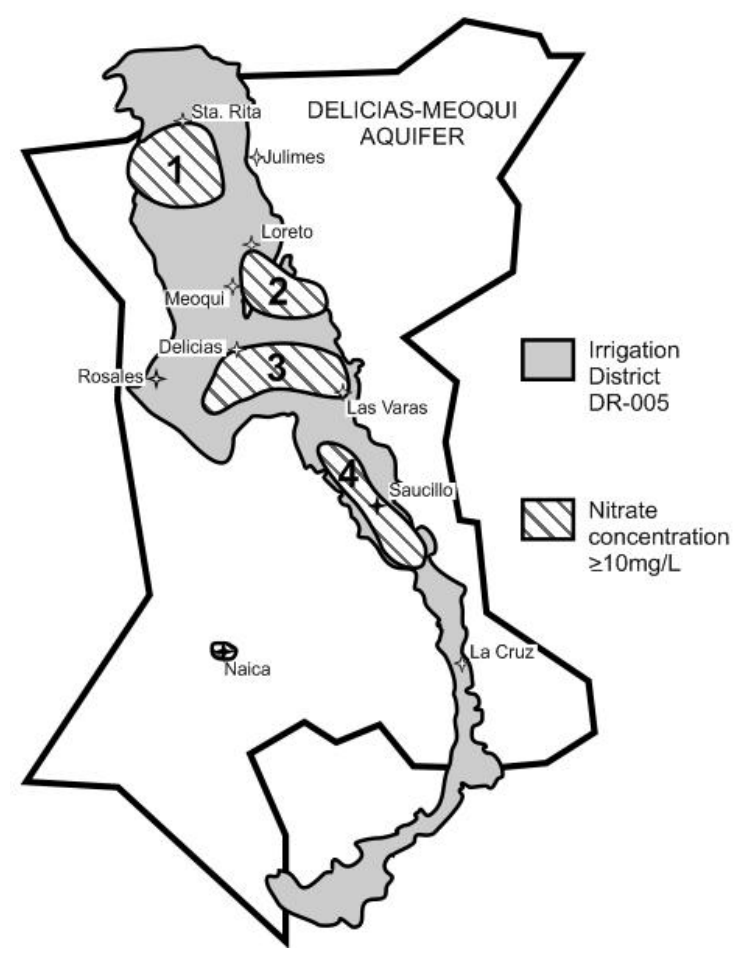

Figure 1: Zones in Delicias-Meoqui aquifer with high nitrates levels. 
The authors recommend additional studies that would link health records with the water quality records for each community to estimate the average long-term exposure to nitrate in drinking water, among other findings. The advantage to this study would be that health institutions already have information concerning the health problems of the inhabitants of the study zones. At the same time, research utilizing denitrification walls to remove nitrate in ground water should be carried out in the studied area. This technology has been proved to be effective in Canada [21] and New Zealand [22].

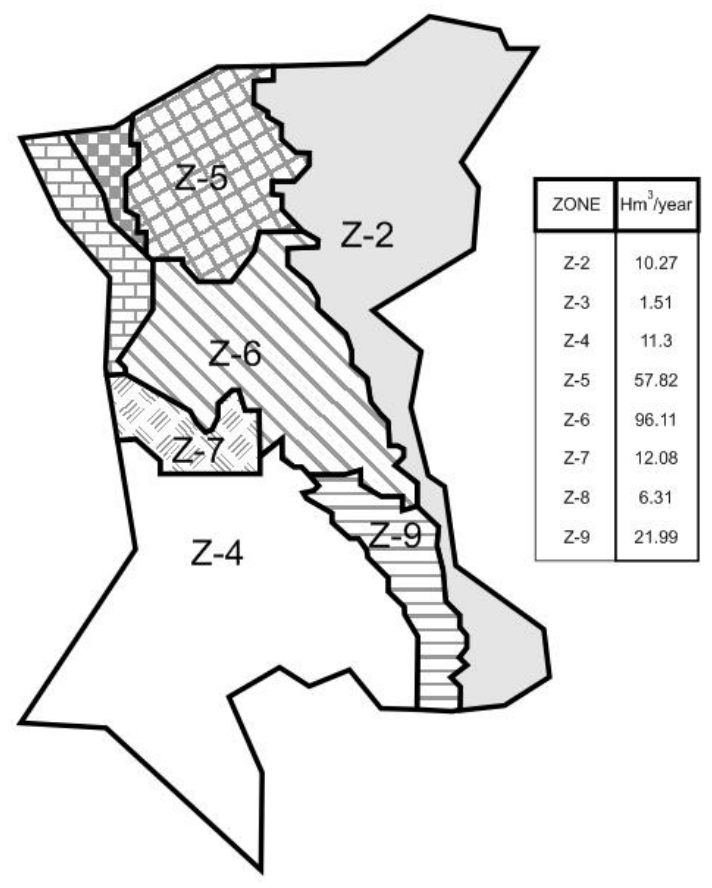

Figure 2: $\quad$ Map of recharge zones in Delicias-Meoqui aquifer (National Water Commission-Mexico, 2005).

\section{Conclusions}

A high percentage of drinking water wells located at Delicias-Meoqui aquifer link nitrate contamination to fertilizers applied on the irrigation district DR-005. The knowledge of specific requirements of fertilizers dose is needed to avoid nitrogen entering the groundwater.

An intense research about the contribution of irrigation to DMA pollution is needed, as is actualizing water quality information and its relationship with geology, the hydrologic variables, human activities influence and the evaluation of agricultural and irrigation techniques. 
Results of this and further studies will contribute to the development of preventive strategies and mitigating measures to protect aquifer from nitrate contamination and to improve knowledge on the management of groundwater resources in proximity to agricultural production systems.

\section{Acknowledgements}

This study was partly supported by the Professors Improvement Program (PROMEP) of the Public Education Ministry (Secretaría de Educación Pública) in Mexico. The information provided by the Water National Commission (Comisión Nacional del Agua) and the Central Board of Water and Sanitation of the State of Chihuahua (JCAS) is greatly appreciated.

\section{References}

[1] Legault, T., Stewart, B., \& Lebedin, J. 2000. In-situ remediation of nitrate in groundwater: Phase 1: Site characterization [online]. Agriculture and Agri-Food Canada. World Wide Web: http://www.agr.gc.ca/pfra/water/nitremed_e.htm

[2] Kross, B.C., Oison, M.L., Ayebo, A. \& Johnsons, J.K. 1995. Humans. In J.E. Rechcigl (Ed.), Boca Raton, FL: Lewis Publishers. 153-214

[3] Ayebo, A., Kross, B.C., Vlad, M., \& Sinca, A. 1997. Infant metahemoglobinemia in the Transylvania Region of Romania. Int. J. of Environ. Health 3(1):20-29.

[4] Lamond, R.E., Powell, G. M. \& Devlin, D. 1999. Nitrate and groundwater [online]. Kansas State University Agricultural Experiment Station and Cooperative Extension Service. World Wide Web: http://www.oznet.ksu.edu

[5] Cuello, C., Correa, P., Haenszel, W, Gordillo, G., Brown, C., Archer, M. \& Tannenbaum, S. 1976. Gastric cancer in Colombia I: Cancer risk and suspected environmental agents. Journal of National Cancer Institute. 57(5):1015-1020

[6] Dorsch, M.M., Scragg, R.K., McMichael, A.J., Baghurst, R.A., \& Dyer, K.E. 1984. Congenital malformations and maternal drinking water supply in rural South Australia: A case-control study. American Journal of Epidemiology 119:473-486

[7] Super, M., Heese, H., Mackenzie, D., Dempster, W.S., Dupless, J. \& Ferreira, JJ.1981. An epidemiologic study of well water nitrates in a group of southwest African Namibian infants. Water Research 15:1265-1270.

[8] Chapman, P.J., Reynolds, B. \& Wheater, H.S. 1996. Experimental investigation of potassium and nitrate dynamics in a headwater stream in Mid-Wales. Chemistry and Ecology. 13:1-19.

[9] Baker, J.L., \& Laflen, J.M. 1982. Effect of crop residue and fertilizer management on soluble nutrient runoff losses. Transactions of the American Society of Agricultural Engineers 25:344-348. 
[10] Rubio, A.H., Wood, K. \& Alanis, H.E. 2004. Water pollution in the Rio Conchos of northern Mexico. Development and application of computer techniques to Environmental Studies X. Ed; G. Latini, G. Passerini, C.A. Brebbia. Witpress. 67-176.

[11] NOM, 1996. Modificación a la norma oficial Mexicana NOM-127-SSAI1994. Salud ambiental. Agua para uso y consumo humano. Límites permisibles de calidad y tratamientos a que debe someterse el agua para su utilización. Diario Oficial.

[12] USEPA, 2002. United States Environmental Protection Agency. Edition of the drinking water Standards and Health Advisories. EPA 822-R-02038, USEPA, office of water, Washington, D.C.

[13] Squillace, P.J., Scott, P.J., Moran, M.J., Nolan, B.T., \& Kolpin, D.W. 2002. VOCs, pesticides, nitrate, and their mixtures in groundwater used for drinking water in the United States. Environmental Science and Technology 36:1923-1930

[14] CNA, 2005. Comision Nacional del Agua. Actualización del Estudio Geohidrológico del Acuífero Meoqui-Delicias, Chihuahua. Subdirección General Técnica. Gerencia de Aguas Subterráneas.

[15] INIFAP, 2006. Instituto Nacional de Investigaciones Forestales, Agrícolas y Pecuarias. Estadísticas climatológicas básicas del estado de Chihuahua. (período 1961-2003). Libro Técnico No. 1. CIRNOC-Chihuahua. P. 151.

[16] INEGI, 1999. Instituto Nacional de Estadística, Geografía e Informática y Gobierno del Estado de Chihuahua. Estudio Hidrológico del Estado de Chihuahua

[17] JCAS, 2006. Junta Central de Agua y Saneamiento del Estado de Chihuahua (JCAS). Personal, May 1999

[18] Volkner, B.G., Ernst, B., Simon, J., Kuefer, R., Bartsch, G. Jr., Bach, D., $\&$ Gschwend, J.E. 2005. Influence of nitrate levels in drinking water on urological malignancies: a community-based cohort study. BJU Int. 95(7):972-976.

[19] Gulis, G., Czompolyova, \& M., Cerhan, Jr. 2002. An ecological study of nitrate in municipal drinking water and cancer incidence in Trnava District, Slovakia. Environ Res. 88(3):182-187

[20] Nolan, B. 2001. Relating nitrogen sources and aquifer susceptibility to nitrate in shallow ground waters of the United States. Ground Water 39, no. 2: 290-299

[21] Robertson, W.D., \& Cherry, J.A. 1995. In situ denitrification of septicsystem nitrate using reactive porous media barriers: Field trials. Ground Water 33:99-111.

[22] Schipper, L.A., \& Vojvodic-Vukovic, M. 2001. Five years of nitrate removal, denitrification and carbon dynamics in a denitrification wall. Water Res. 35:3473-3477. 